\title{
Intranasal Nalbuphine Formulation for Faster Management of Pain in Prehospital Scenario; Its Safety and Comparative Efficacy in Animal Models
}

\author{
Kushagra Khanna ${ }^{1,2}$, Deeksha Sharma1, Ritu Karwasra', Nitin Sharma ${ }^{1,3}$, Dhruv Kumar Nishad', \\ Harvinder Popli ${ }^{2, *}$, Aseem Bhatnagar ${ }^{1}$
}

${ }^{1}$ Department of CEPIN, Institute of Nuclear Medicine and Allied Sciences (INMAS) Defence Research and Development Organization, Timarpur, Delhi, INDIA.

2Department of Pharmaceutics, Delhi Pharmaceutical Science and Research University, Mehrauli Badarpur Road, Sector 3 Pushp Vihar, New Delhi, INDIA.

${ }^{3}$ Department of Pharmacy, Meerut Institute of Engineering and Technology. Meerut, Uttar Pradesh, INDIA.

\begin{abstract}
Aim: Nalbuphine (NLB) is an approved opioid analgesic for the management of severe pain in wounds, battlefield injuries and is recommended to subsidize labour pain during childbirth. The study aims to develop an intranasal opioid formulation for faster pain relief. Secondly to avoid patient inconvenience and make it available for buddy care. In case of war, accident or any natural calamities the feasibility of giving drugs from the parenteral route is not feasible as it requires high skilled medic/paramedic staff. Materials and Methods: Different formulations were made using NLB as an Active Pharmaceutical Ingredient (API), prepared formulations (F1-F10) were characterized and evaluated for various parameters. The formulation F5 was optimized as it met the desired criteria. F5 was further studied for its efficacy in an established pain model using Eddy's hot plate method and pain scoring in animals. Pharmacodynamics study was conducted in Sprague dawley rats which were further verified by gamma scintigraphy using ${ }^{99 \mathrm{~m}} \mathrm{Tc}$-pertechnetate labelled NLB showing significant and rapid deposition in the brain tissue. Results: NLB nasal formulation was optimized successfully; at $\mathrm{pH} 6.4 \pm 0.10$ and viscosity $2.5 \pm 0.13$ (cps). Osmolarity and percent drug release of optimized nasal drop at $240 \mathrm{~min}$ was found to be $288 \pm 18$ milliosmol/litre and $96.98 \pm 3.1 \%$ respectively. Gamma scintigraphy study results revealed that the formulation (F5) was able to deliver NLB to the brain within 10 mins of administration and remained localized up to 240 min. Pre-clinical subacute toxicity profiling of optimized formulation was done in Sprague dawley rats at $3 \mathrm{X}$ dose. Conclusion: Data obtained from the study indicate that the developed NLB nasal formulation has better efficacy for pain management than conventional I.M injection.
\end{abstract}

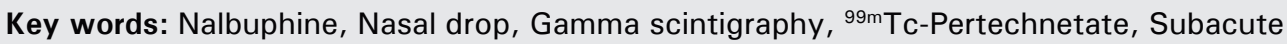
toxicity.

\section{INTRODUCTION}

A society known as "International Association for the Study of Pain" (IASP) is an active society at international level which imparts learning and recent updates in research, education and policies for prevention and treatment of pain. An International Association for the study of pain' (IASP) has delineated pain as "an obnoxious" sensory and poignant experience associated with potential tissue damage. ${ }^{1}$ It is an intricate phenomenon which comprises of three components i.e. physiological, emotional and behavioural. ${ }^{2}$ Relief from pain is important for practical, physiological and humanitarian reasons. ${ }^{3}$ Management of pain in war victims, accidental victims in pre-hospital conditions or while transportation of injured personnel
Submission Date: 18-06-2019; Revision Date: 03-10-2019; Accepted Date: 06-11-2019

DOI: 10.5530/ijper.54.2.36 Correspondence:

Prof. Harvinder Popli,

Dean and Head, Department of Pharmacy, Department of Pharmaceutics, Delhi Pharmaceutical Science and, Research University, Mehrauli Badarpur Road, Sector 3 Pushp Vihar, New Delhi, INDIA.

Phone: +919899700704

E-mail: popli.harvinder@ gmail.com

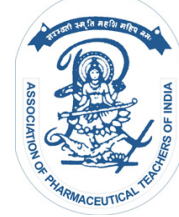

www.ijper.org 
is always a prime concern. ${ }^{4}$ Most of the analgesic agents used to relieve pain are administered through parental route. But in the absence of expert medical attendants or low visibility, the feasibility of parental injection is close to negligible. Thus, other modalities for the delivery of analgesic agents to fasten the onset of action will be a boon for soldiers in war scenarios as well as for accidental victims. ${ }^{5}$

Nalbuphine (NLB) is one such analgesic that is available in the market as parenteral formulations i.e Intramuscular (i.m), Intravenous (i.v) or Subcutaneous (s.c) route of injection and used for pain management in emergency situations. ${ }^{6}$ The parenteral formulations were available in two different dosage forms 10 and $20 \mathrm{mg}$ and its onset of action depend upon the route of delivery. It is reported to act within $30 \mathrm{~min}$ after s.c or i.m injection or within 2 to 3 min of i.v injection. $^{7}$ I.V injection possesses no patient compliance and requires trained professionals to treat emergency situations like warfare conditions. The Selection of precise delivery systems is one of the most prevalent challenges that a scientist faces while designing a suitable dosage form. For the treatment of mass casualties, i.v or i.m routes are not practically feasible; therefore it is required to find alternative routes to combat such problems more effectively ${ }^{8}$ so, one of the alternative routes can be intranasal delivery, a painless, self-administrable and can be easily employed in emergencies. ${ }^{9,10}$ For better improvement in efficacy profile, permeation enhancers and bioadhesive agents can be added with intranasal formulations. ${ }^{11,12}$ Nasal route proved itself a promising route because various physiological and histological studies in human beings stated that mucosa in the olfactory nerve foramen is connected to the cerebral perivascular spaces and subarachnoid spaces of the olfactory lobes in the brain which makes a possible pathway for drug transport. ${ }^{13}$ It was observed that CSF runs directly below the olfactory mucosa that designates nasal drug delivery as an effective way of delivering drugs directly to the brain. ${ }^{14}$ Nasal route provides various other benefits such as large surface area, noninvasive delivery or target delivery. ${ }^{15}$ Nasal drops and nasal spray are used in treating nasal problems such as rhinitis and nasal congestion. ${ }^{16}$ Moreover in nasal drop and spray, the release of the drug occurs fast and directly through the nose. ${ }^{17}$

Literature suggested that nasal formulations have also been used in the treatment of Alzheimer's disease, Parkinson's disease and hormone replacement therapy. ${ }^{18}$ We hypothesize to use this route for the first time, delivery of centrally acting analgesic agents to be used during emergency circumstances in pre-hospital scenarios. Therefore, the objective of the present study is to develop a safe and effective nasal formulation of NLB using bio adhesion principles and assessment of its bioavailability to be carried by gamma scintigraphy technique.

\section{MATERIALS AND METHODS}

\section{Animals}

All experiments were carried out in accordance with European Community guidelines for use and experimentation on animals. The protocol for the animal study was duly reviewed and approved by the Institutional Animal Ethics Committee (INM/IAEC/2017/01). Sprague dawley rats (150-250g) and New Zealand rabbits (3-4 kg) were housed under standard laboratory conditions (temperature $25 \pm 2^{\circ} \mathrm{C} ; 55 \pm 5 \%$ RH (Relative Humidity). Animals were housed into polypropylene cages subjected with free access to standard laboratory diet (Hindustan Animal Feeds, Gujarat India) and tap water.

\section{Chemicals}

NLB base was obtained as a gift sample from Rusan Pharmaceuticals Ltd, Dehradun, India. The chitosan powder was obtained from M/s Aura Biotechnologies Pvt. Ltd. Chennai, Tamil Nadu, India; PEG-400 (Polyethylene Glycol) from S.D Fine Chem., Mumbai and sodium chloride from Loba chemie Pvt. Itd, Mumbai, India and all other chemicals used in various experiments were of LR (Laboratory Reagent) grade and purchased from a local vendor. ${ }^{99 \mathrm{~m}}$ Tc Pertechnetate radioisotope was procured from the regional centre of Board of Radiation Isotope and Technology (BRIT), at Institute of Nuclear Medicine and Allied Sciences (INMAS), Delhi.

\section{Preformulation studies: Determination of $\lambda_{\max }$}

NLB solution $(10 \mu \mathrm{g} / \mathrm{mL})$ was prepared in various solvents like ethanol, methanol and phosphate buffer (pH 6.5) respectively in a volumetric flask. ${ }^{19}$ The solutions prepared were analyzed at the wavelength of $200-400 \mathrm{~nm}$ using Agilent Technology Cary-60 (UV- Vis Spectrophotometer) to determine $\lambda_{\max }$.

\section{Preparation of standard curve}

Accurately weighed amount of NLB base (10 mg) was dissolved with $10 \mathrm{~mL}$ Phosphate buffer 6.5 to prepare a stock solution of $1000 \mu \mathrm{g} / \mathrm{mL}$ concentration which was further diluted with Phosphate Buffer to get serial dilutions of $10,20,30,40,50 \mu \mathrm{g} / \mathrm{mL}$ of NLB. The Absorbance of samples was recorded using a UV-Vis spectrophotometer at $284 \mathrm{~nm} \lambda_{\max }$. Graphs were plotted 
by taking absorbance on $\mathrm{Y}$-axis and concentration on $\mathrm{X}$-axis.

\section{Solubility studies}

The solubility of NLB base in various solvents like ethanol, methanol, acetone and chloroform was ascertained by dissolving surfeit amount of drug in $1 \mathrm{~mL}$ of each solvent. The drug was added to the stoppered vial and mixed using a vortex mixer. The vials were kept at $25 \pm 1^{\circ} \mathrm{C}$ for $72 \mathrm{hr}$ to get equilibrium. After $72 \mathrm{hr}$ samples were centrifuged for $15 \mathrm{~min}$ at $3000 \mathrm{rpm}$. The supernatant was filtered through a $0.45 \mu \mathrm{m}$ membrane filter. The concentration of drug in each solvent was determined by UV-Vis spectrophotometer.

\section{Partition Coefficient}

The Partition coefficient of the drug was determined by the Shake flask method. According to previously prescribed methods ${ }^{20,21}$ the flask containing a saturated solution of drug in octane/water (1:1) was shaken at $25 \pm 1^{\circ} \mathrm{C}$ for $24 \mathrm{hr}$ in a separating funnel, the mixture was transferred and allowed to equilibrate for $10 \mathrm{hr}$. The water and Octane phase was separated and filtered. The concentration of drug in each phase was estimated by UV- Vis spectrophotometer at $284 \mathrm{~nm}$. Further partition coefficient was computed using this formula.

$$
\begin{aligned}
\text { Partition Coefficient }= & \begin{array}{l}
\text { Concentration of drug } \\
\text { in organic phase } \\
\text { Concentration of drug } \\
\text { in aqueous phase }
\end{array} \times 100
\end{aligned}
$$

\section{Compatibility Studies}

Drug and excipients compatibility was carried out using a mixture of NLB and excipients with moisture. The drug and excipients were taken in 1:1 ratio and $0.45 \%$ water is added as the worst condition to observe the effect of moisture on drugs and excipients. The mixture was then placed in a glass vial, sealed and hoarded in an oven at $50 \pm 2^{\circ} \mathrm{C}$ for
15 days. On the $7^{\text {th }}$ and $15^{\text {th }}$ day, the mixture was evaluated for physical changes including caking, discoloration and liquefaction and chemical change using UV-Vis spectrophotometer. Further, the samples were evaluated through Fourier Transformation- Infrared Spectroscopy (JASCO- FT/IR-4600) to examine the molecular level interaction.

\section{Formulation Development}

Ten different formulations of NLB nasal drops were prepared using chitosan in the concentration ranging from 0.5 to $2.5 \%$ as a mucoadhesive polymer. The $\mathrm{pH}$ of the formulations having chitosan was kept around 6.0 or below as chitosan becomes insoluble at higher $\mathrm{pH} .{ }^{22}$ Required amount of NLB $(0.5 \%)$ was dissolved in 50:50 ratio of PEG 400 and ethanol (as solvent) with varying amount of chitosan, followed by addition of $\mathrm{NaCl}(0.9 \%)$ and benzalkonium chloride $(1 \%)$ and the final volume was made up by Milli Q water (Table 1). The $\mathrm{pH}$ of developed formulation was examined using $\mathrm{pH}$ meter and was adjusted between 5.5 - 6.5 (as of nasal mucosa). Nitrogen was purged in the prepared formulation to provide oxygen-free environment to improve stability. ${ }^{23}$ Batteries of tests were performed to optimize the developed formulation in the manner described below.

\section{Formulation characterization \\ $\mathrm{pH}$}

All formulations prepared were analyzed using digital $\mathrm{pH}$ meter (Systronics 336).

\section{Osmolarity}

Tonicity of formulation substantially affects the nasal mucosa, so generally, an isotonic formulation is preferred. The Osmolality of the prepared formulation was measured using Osmomat ${ }^{\circledR} 030$.

\section{Clarity test}

To determine whether the prepared formulation is free from any particulate matter or not, the clarity test was

\begin{tabular}{|c|c|c|c|c|c|c|c|c|c|c|c|}
\hline \multicolumn{10}{c|}{ Table 1: Composition of Nalbuphine nasal drop (\%). } \\
\hline S.No & Ingredients & F1 & F2 & F3 & F4 & F5 & F6 & F7 & F8 & F9 & F10 \\
\hline $\mathbf{1}$ & Drug (\%) & 0.5 & 0.5 & 0.5 & 0.5 & 0.5 & 0.5 & 0.5 & 0.5 & 0.5 & 0.5 \\
\hline $\mathbf{2}$ & Chitosan (\%) & 0.25 & 0.5 & 1.0 & 1.5 & 2.0 & 2.5 & 2.0 & 2.0 & 2.0 & 2.0 \\
\hline $\mathbf{3}$ & PEG 400 (\%) & 10 & 20 & 30 & 40 & 50 & 60 & - & 5 & 15 & 25 \\
\hline $\mathbf{4}$ & Ethanol & 5 & 5 & - & - & - & - & 5 & - & - & - \\
\hline $\mathbf{5}$ & Nacl & 0.9 & 0.9 & 0.9 & 0.9 & 0.9 & 0.9 & 0.9 & 0.9 & 0.9 & 0.9 \\
\hline $\mathbf{6}$ & $\begin{array}{c}\text { Benzalkonium } \\
\text { Chloride }\end{array}$ & 0.01 & 0.01 & 0.01 & 0.01 & 0.01 & 0.01 & 0.01 & 0.01 & 0.01 & 0.01 \\
\hline $\mathbf{7}$ & Water & q.s & q.s & q.s & q.s & q.s & q.s & q.s & q.s & q.s & q.s \\
\hline
\end{tabular}


performed. The Formulation was shifted into a test tube and observed separately in the black and white background under light using clarity test apparatus.

\section{Viscosity}

Apparent viscosity of prepared nasal formulation was measured using R/S-CPS-Plus Brookfield Remoter (Brookfield Engineering, Massachusetts, USA) at $37 \pm 0.5^{\circ} \mathrm{C}$. Instrument was equipped with cone and plate geometry $\left(4^{\circ} / 40 \mathrm{~mm}\right)$. The temperature was regulated using pettier thermo regulatory (Brookfield PTR-I) and obtained data was recorded with the help of software RHEO 2000 version $2.5 .^{24}$ Nasal formulation $(1 \mathrm{~mL})$ was placed in measuring the gap between the rotating cone and the stationary lower plate and allowed to equilibrate for $5-10 \mathrm{~min}$ at $37 \pm 0.5^{\circ} \mathrm{C}$. Apparent viscosity was measured at 10 shear rate $\left(\mathrm{s}^{-1}\right)$.

\section{Sterility test}

To determine the presence of any microorganism in the prepared formulation, a sterility test was performed. The Prepared formulation was diluted and divided into two portions. One portion was incubated at $37^{\circ} \mathrm{C}$ into Soya bean casein digested media for 1 day to determine any bacterial growth and another portion was incubated at $23^{\circ} \mathrm{C}$ over a period of 7 days for identification of fungal growth.

\section{Mucoadhesive strength}

The mucoadhesive strength of the developed formulation was determined using goat nasal mucosa $\left(2.56 \mathrm{~cm}^{2}\right)$ which was adhered on the probes with lower and upper surface of modified balance ${ }^{25} 2 \% \mathrm{v} / \mathrm{v}$ formulation was positioned between the mucosal layers and was equilibrated at $37^{\circ} \mathrm{C}$ for $15 \mathrm{~min}$ to ensure close contact between tissues and sample. The Determination of mucoadhesive strength was done with minimum weight required to disconnect nasal epithelia from the developed formulation using the following equation.

$$
\mathrm{N}=\mathrm{mg} / 1000
$$

$\mathrm{m}$ : weight required to separate polymer solution from goat nasal mucosa

g: acceleration due to gravity $\left(9.81 \mathrm{~m} / \mathrm{s}^{2}\right)$

\section{In-vitro Permeability studies}

The in-vitro drug release pattern of NLB nasal drop formulation for brain delivery was assessed using the dialysis membrane (mol. Wt. $12-14 \mathrm{kDa}$ ) in Franz diffusion cell. Phosphate buffer $\mathrm{pH} 6.5$ was employed as release media. The dialysis bag used for the study was activated prior to commencement of the experiment. ${ }^{26} \mathrm{~A}$ cut section of the dialysis membrane was washed in running water for 3-4 $\mathrm{hr}$ followed by treatment of cut section with sodium sulphide solution $(0.3 \% \mathrm{w} / \mathrm{v})$ at $80^{\circ} \mathrm{C}$ for $1 \mathrm{~min}$ to remove sulphur containing compounds. Finally, it was rinsed with hot water $\left(60^{\circ} \mathrm{C}\right)$ for $2 \mathrm{~min}$, followed by acidification with a $0.2 \%(\mathrm{v} / \mathrm{v})$ solution of sulphuric acid $\left(\mathrm{H}_{2} \mathrm{SO}_{4}\right)$ and thereafter washed with hot water to remove the acidic residue. ${ }^{27}$ Then, the dialysis membranes were immersed overnight in the diffusion medium before conducting the experiment.

Permeation studies were carried out in Franz diffusion cell, dialysis membrane was positioned between donor and receptor compartment containing $15 \mathrm{~mL}$ phosphate buffer $\mathrm{pH} 6.5$ and temperature was maintained at $37 \pm 0.5^{\circ} \mathrm{C}$ and stirred at $300 \mathrm{rpm} .100 \mu \mathrm{L}$ of NLB nasal drop was placed in the donor compartment. At a predetermined time interval, $1 \mathrm{~mL}$ of the sample was withdrawn from the receptor compartment and the sink condition was maintained by adding the same quantity of fresh phosphate buffer in the receptor compartment. The samples withdrawn were analyzed spectrophotometrically at a wavelength of $284 \mathrm{~nm}$ and the concentration of NLB release was calculated from the standard plot. Data was represented in terms of percentage drug release per unit surface area.

\section{Toxicity Studies-Draize Eye Test}

The Draize test is an acute toxicity test slightly modified to the previously described method of Wilhelmus, 2001. The right eye of the rabbit was designated as a test eye; the contralateral eye served as control and was left untreated. In the right eye, $0.1 \mathrm{~mL}$ of the test formulation was instilled and the left eye served as a control with no treatment. The temperature of both eyes was recorded using Infrared Camera (Wahl's Heat Spy ${ }^{\circledR}$ HSI3000) at a regular time interval to observe any increase in temperature, edema, redness or discharge from the eye and was noted. ${ }^{28}$

\section{Sub-acute toxicity study}

The toxicity study of NLB was carried out in accordance with the OECD guideline 407. The animals were divided into three groups $(n=6)$. Group 1 served as

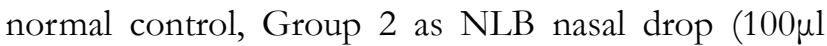
of $0.2 \mathrm{mg} / \mathrm{kg}$ ) and Group 3 served as NLB formulation at $0.6 \mathrm{mg} / \mathrm{kg}$ dose. All rats were observed daily up to 28 days for pharmacologic responses or evident signs of toxicity (dizziness, hair-fall, rashes and edema). Body weights of animal and food consumption were monitored before the start of the study and throughout the study. Blood samples were withdrawn at different time points, biochemical 
tests (Cobas Integra e411) and haematological parameters (Beckmen coulter 5 part) were studied ( $\mathrm{Hb}(\mathrm{gm} / \mathrm{dL})$, TLC (/cumm), neutrophil (\%), lymphocyte (\%), eosinophil (\%), monocyte (\%), basophil (\%), platelet count (x10^3/uL), blood urea, serum creatinine, serum bilirubin $(\mathrm{mg} / \mathrm{dl})$, alkaline phosphatase (IU/L), SGPT (Serum glutamic pyruvic transaminase)/ALT (U/L), SGOT (serum glutamic-oxaloacetic transaminase)/AST (U/L) were estimated for all groups to study the body weight variations, food and water intake. Histopathology evaluation was performed following the method given by Brat DJ, 2010. ${ }^{29}$ The brain of the animals used in sub-acute nasal toxicity was isolated after sacrificing them using $\mathrm{CO}_{2}$ euthanasia on the $28^{\text {th }}$ day. Isolated brain tissues were preserved in 10\% neutral buffered formalin for histopathological observations. ${ }^{30}$ Brain tissues were cut into thin sections using microtome and then stained with hematoxylin and eosin. Tissue sections were later observed under a light microscope for any histopathological changes.

\section{In-vivo efficacy study of NLB Nasal formulation}

The paws (hind paws and forepaws) of rats are very sensitive and responsive to heat and variation in temperature. The animals were placed on the hot plate (Eddys Hot Plate) ${ }^{31}$ and temperature was controlled at $55^{\circ} \mathrm{C}$ and the time for either licking or jumping of the animal was recorded by a stop-watch. The latency of response was recorded before and after 10, 30 and 60 min following intramuscular administration of the standard against the test compound through intranasal delivery. A cut-off reaction time of $15 \mathrm{sec}$ was chosen to avoid physical injury to the animal. Pain scoring, on a scale of $0-2$ was determined at predetermined time intervals $(0,30$ and $60 \mathrm{~min})$.

0 score (No response)

1 score (Nose and cheek flattering)

2 score (Orbital Tightening

\section{Pharmacoscintigraphy evaluation: Radiolabelling of NLB with ${ }^{99 m} T C$}

NLB was radiolabelled with ${ }^{99} \mathrm{~m}$ Tc-pertechnetate in the presence of stannous chloride $\left(\mathrm{SnCl}_{2}\right)$ acting as a reducing agent in dry form according to the optimized protocol. Instant thin-layer chromatography (ITLC) was carried out to determine the labelling efficiency. ${ }^{32}$ From the stock solution of the radio-complex formed, 2-3 $\mu \mathrm{L}$ was applied at a point $1 \mathrm{~cm}$ above from the bottom of the ITLC-SG strip (stationary phase) and allowed to run for approximately $10 \mathrm{~cm}$ using acetone as mobile phase. Afterwards, the chromatogram was cut in the ratio of 70:30 (Bottom: Top) and counts of each chromatogram were taken using gamma counter $\left(\right.$ Caprac $^{\circledR}$-t wipe test / well counter, Capintech). The activities of free and bound ${ }^{99 \mathrm{~m}} \mathrm{Tc}$ were determined using the formula mentioned below. The purity of radiopharmaceuticals was determined by the conventional method using ITLC where EAW (Ethanol: Ammonia: Water $=3: 2: 5$ ) used as a mobile phase to determine Technetium-99m respectively. Effect of $\mathrm{pH}$ $(4.0,6.0,7.0$ and 8.0$)$ and varying temperatures $\left(25^{\circ} \mathrm{C}\right.$, $30^{\circ} \mathrm{C}$ and $60^{\circ} \mathrm{C}$ ), on radiolabel complex of NLB, was evaluated and optimized. ${ }^{33,34}$

$$
\text { Radiolabeling efficiency }=\frac{\text { Counts on bottom } \times 100}{\text { Counts on top }+ \text { bottom }}
$$

\section{Radio complex stability studies}

\section{Saline Stability}

An in-vitro stability study of radio-complex was carried out by mixing $100 \mu \mathrm{L}$ of ${ }^{99 \mathrm{~m}} \mathrm{Tc}$ - NLB with $900 \mu \mathrm{L}$ of saline, the solution was vortexed for uniform mixing and kept at room temperature. Small aliquots samples were withdrawn at different intervals up to $24 \mathrm{hr}$ and stability of ${ }^{99 \mathrm{~m}} \mathrm{Tc}-\mathrm{NLB}$ was determined using acetone as a mobile phase by standard ITLC method. The developed strips were cut in a ratio of 70:30 and radioactivity in each segment was measured to determine the stability of the ${ }^{99 \mathrm{~m}}$ Tc-pertechnetate-NLB complex. ${ }^{33}$

\section{Serum Stability}

The stability of radio-complex NLB was also performed in serum by mixing $100 \mu \mathrm{L}$ of ${ }^{99 \mathrm{~m}} \mathrm{Tc}$ - NLB with $900 \mu \mathrm{L}$ of serum, was vortexed for uniform mixing and kept at room temperature. Small aliquots of the mixture were withdrawn $(2-3 \mu \mathrm{L})$ from the radiolabeled complex and applied at a point $1 \mathrm{~cm}$ above from the bottom of the ITLC-SG strip (stationary phase) and allowed to run for approximately $10 \mathrm{~cm}$ using acetone as mobile phase. Afterward, the chromatogram was cut in the ratio of 70:30 (Bottom: Top) and radioactivity in each segment was measured to calculate the serum stability of the drug. This procedure was carried up to $24 \mathrm{hrs}$ at different time intervals. ${ }^{33}$

\section{In-vivo Biodistribution studies in animal model}

Biodistribution study was carried out to observe the distribution pattern of NLB in various organs of experimental animals. Sprague dawley rats $n=6$ (average weight $200 \mathrm{~g}$ ) were selected for bio-distribution studies. Rats were instilled with ${ }^{99 \mathrm{~m}} \mathrm{Tc}$-NLB complex into the nostrils with the help of LDPE (Low density polyethylene) tubing attached to a micropipette, with $0.1 \mathrm{~mm}$ internal diameter. The rats were held from the back 
in slanted position during the administration of nasal drop..$^{35}$ At different time interval i.e. 15, 30, 60, 120 and $240 \mathrm{~min}$ of post-administration, animals were sacrificed through $\mathrm{CO}_{2}$ euthanasia and organs were excised, washed and counts were taken in a gamma counter $\left(\right.$ Caprac $^{\circledR}$-t wipe test / well counter, Capintech).

\section{Gamma Scintigraphy evaluation}

Brain targeting of prepared NLB formulation was further confirmed in healthy Sprague dawley rats (weight $161 \mathrm{~g})$ using the gamma scintigraphy method. Animals were fasted for $24 \mathrm{hr}$ before commencement of study. Radiolabelled nasal drops of the optimized formulation containing (50 $\mu \mathrm{Ci}$ of ${ }^{99 \mathrm{~m}} \mathrm{Tech}$ etium pertechnetate) was administered to the animals through nasal route. ${ }^{36}$ Images of the animal were captured by gamma camera (Siemens T2 SPECT-CT) at different time points i.e. 15, 30, 60, 120 and $240 \mathrm{~min}$. The experimental variables were kept constant throughout the study.

\section{Stability Studies}

Stability studies were carried out in accordance with ICH (International Council for Harmonization) guidelines and the optimized formulation was analyzed for $\lambda_{\text {max }}$ and was further evaluated for physical appearance, $\mathrm{pH}$, osmolarity and drug content at pre-determined time intervals i.e. $0,1,2,4$ and 6 months.

\section{Statistical analysis}

The data were represented as Mean \pm S.E.M or Mean \pm S.D (wherever applicable). Statistical analysis was carried out using one-way ANOVA (Analysis of Variance), followed by Tukey's multiple comparison test, was used for calculation of significance in recorded data with GraphPad In stat 7.0 software. $p<0.05$ considered being significant.

\section{RESULTS}

\section{Pre-formulation Studies: Determination of $\lambda_{\max }$ by UV- Vis spectrophotometer}

The diluted sample of NLB formulation was analyzed for absorbance maxima under UV-Vis spectrophotometer and the maximum absorbance of NLB was observed at $284 \mathrm{~nm}$ (Figure 1).

\section{Solubility Studies}

NLB base solubility was analyzed in various solvents i.e. methanol, ethanol, acetone and water by keeping the saturated solution for $72 \mathrm{hr}$. The solubility of NLB base was found $18 \mathrm{mg} / \mathrm{mL}$ in methanol, $5 \mathrm{mg} / \mathrm{mL}$ in acetone, $10 \mathrm{mg} / \mathrm{mL}$ in chloroform and was found to be maximum in ethanol, which was $20 \mathrm{mg} / \mathrm{mL}$

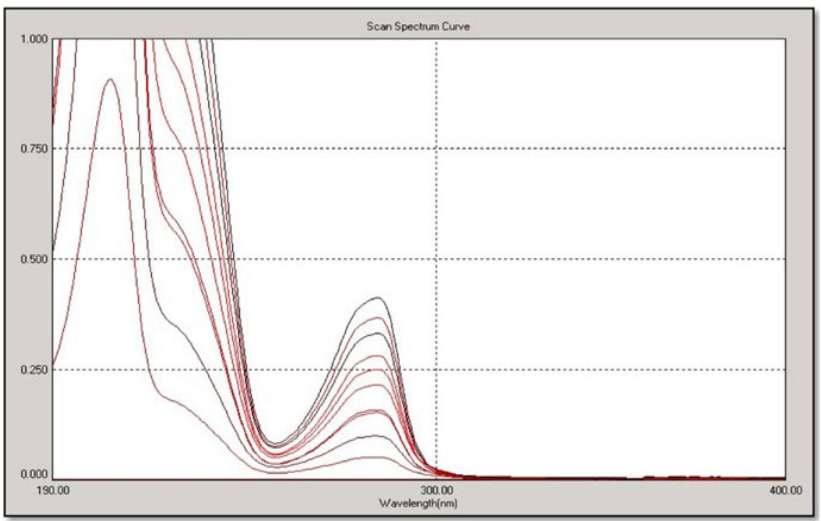

Figure 1: Maximum Wavelength of Nalbuphine was observed at $284 \mathrm{~nm}$.

\section{Partition Coefficient}

The $\mathrm{P}_{\mathrm{o} / \mathrm{w}}$ value of $\mathrm{NLB}$ was found to be $1.39 \pm 0.043$ which is in close agreement to reference value of 1.42 .

\section{Compatibility Studies}

Table 2 depicts the physical and chemical changes on the $7^{\text {th }}$ and $15^{\text {th }}$ day of study and it was observed that there were no physical changes like caking, discoloration and liquefaction in the mixture in both normal and accelerated conditions to which the mixture was exposed. The chemical changes were determined through absorption maxima $\left(\lambda_{\max }\right)$ by UV-Vis spectrophotometer. The results confirmed that there were no interactions between Chitosan and NLB in normal and accelerated conditions.

The characteristic absorption band of chitosan was found to be at $1647.50 \mathrm{~cm}^{-1}$, which was assigned as stretching vibration of an amino group and the peak at 3356.93, 3286.41 corresponds to $\mathrm{N}-\mathrm{H}$ and $\mathrm{O}-\mathrm{H}$ stretching. $2873.38 \mathrm{~cm}^{-1}$ illustrates $\mathrm{C}-\mathrm{H}$ asymmetric stretching vibration respectively. A peak at $1375.58 \mathrm{~cm}^{-1}$ confirms the symmetrical $\mathrm{CH}_{3}$ deformations (Figure 2). The FT-IR spectrum of NLB base exhibited a broadband between $3426-3498 \mathrm{~cm}^{-1}$, depicted to the $-\mathrm{OH}$ and $\mathrm{NH}+$ groups. Some other peaks were obtained at 2949 and 1640, show the presence of alkyl C-H stretch and $\mathrm{C}=\mathrm{O}$ group (Figure 2). Presence of all characteristic peaks of NLB and absence of a newly developed peak in drug: polymer physical mixture was in accordance with the stability of drugs during formulation development (Figure 2).

\section{Formulation Development}

With the help of the aforementioned formulas, the nasal drop of NLB was successfully prepared and was evaluated for various parameters (Table 1). 


\begin{tabular}{|c|c|c|c|c|c|c|c|c|}
\hline \multicolumn{4}{|c|}{ Table 2: Compatibility study of NLB. } \\
\hline Mixture & \multicolumn{4}{|c|}{ On $7^{\text {th }}$ Day } & \multicolumn{4}{c|}{ On 15 th $^{\text {Day }}$} \\
\hline & \multicolumn{2}{|c|}{$\begin{array}{c}\text { Physical } \\
\text { Change }\end{array}$} & $\begin{array}{c}\text { Chemical } \\
\text { Change }\end{array}$ & \multicolumn{3}{c|}{$\begin{array}{c}\text { Physical } \\
\text { Change }\end{array}$} & $\begin{array}{c}\text { Chemical } \\
\text { Change }\end{array}$ \\
\hline & D & C & L & $\lambda_{\max }$ & D & C & L & $\lambda_{\max }$ \\
\hline A1 & - & - & - & 285 & - & - & - & 285 \\
\hline A2 & - & - & - & 285 & - & - & - & 285 \\
\hline
\end{tabular}

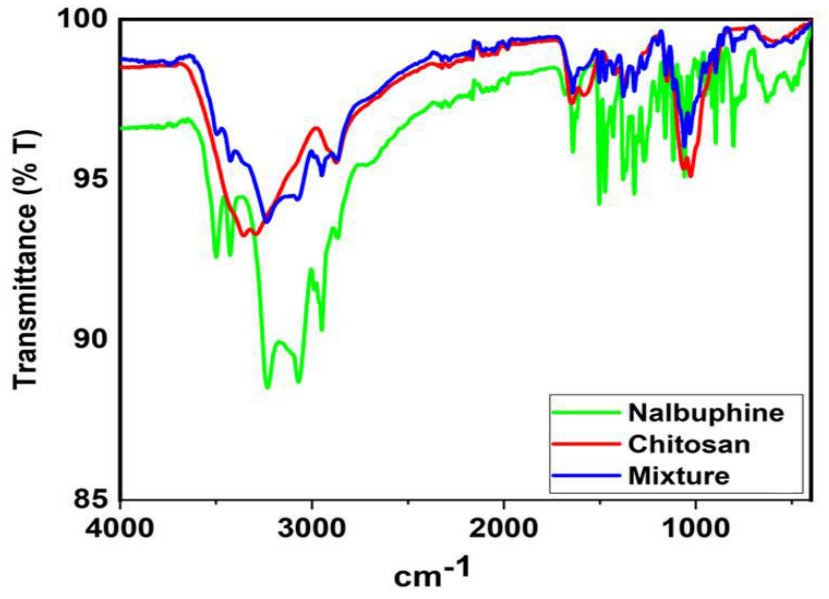

Figure 2: FT-IR of (A) NLB (B) Chitosan (C) Mixture of NLB and Chitosan.

\section{Formulation characterization: Physiochemical Evaluation}

The formulated nasal drops of NLB were evaluated for physicochemical tests including physical appearance, viscosity, $\mathrm{pH}$ and clarity. The physical appearance of the nasal drop was tested by visual observations. The results of the physicochemical evaluation of formulation are detailed in (Table 3). The $\mathrm{pH}$ of all formulations was found to lie within 5.5-6.8, which is an equivalent $\mathrm{pH}$ range of normal nasal mucosa. The Viscosity of nasal drops increases with an increase in PEG and chitosan concentration. After the application of nasal drop into nasal mucosa of rats, no sign of redness, itching and irritation was observed. The results of the physicochemical parameter for all formulations depict that F5 is the optimized formulation for delivering and to sustain a normal physiological biliary movement.

\section{Sterility Test}

Nasal drop containing chitosan was subjected to sterilization using the Gamma sterilization technique and was poured on soybean casein media plate and no colony was formed by bacteria or fungi in 7 days of the experimental period.

\section{Mucoadhesive strength}

The formulation exhibited $319 \pm 15 \mathrm{~N} / \mathrm{m}^{2}$ mucoadhesive strength at 15 min contact time.

\section{In-vitro Permeation Studies}

Various prepared formulations were subjected to Franz diffusion cell to study drug permeation through the dialysis membrane. Permeation data of all batches are depicted in (Figure 3) and all the formulations showed permeation from the dialysis membrane in the range of $41.9 \pm 2.2$ to $97.98 \pm 3.1$ at $240 \mathrm{~min}$. Formulation coded with F5 was considered as optimum formulation because it depicted a maximum cumulative permeation $97.98 \pm 3.1 \%$ when compared to other formulations.

\section{Toxicity Studies: Draize Test}

Temperatures of test and control eyes were recorded by Infrared Camera. There was no rise in temperature of test eye as compared to control eye and no observation of redness, erythema and edema was observed (Figure 4).

\section{Subacute toxicity}

No mortality was observed in the treatment group during the study period of 28 days. The chronic administration of formulation $\mathrm{F} 5$ at a dose of $0.6 \mathrm{mg} / \mathrm{kg}$ did not produce any significant changes in the haematological and biochemical parameters as compared to the normal control group (Table 4). All animals survived till their necropsy was scheduled and their behavioral and physical assessment did not illustrate any treatmentrelated adverse effects as compared to normal control group. No pathological changes were observed in brain sections of the treatment group as compared to control group animals (Figure 5). The targeting of nasal formulation F5 is on the brain tissue, so pathological changes in brain sections were examined.

\section{In-vivo efficacy Study of NLB Nasal drop formulation}

Heat latency in rat was determined at 10, 30, $60 \mathrm{~min}$ after intramuscular administration of calculated dose in animal model and it was observed that the response of rat with respect to time was $3.54 \pm 0.34,5.35 \pm 0.09$, $7.21 \pm 0.06 \mathrm{sec}$ respectively whereas, in case of intranasal administration of NLB formulation, the result at same time interval was $6.00 \pm 0.41,8.24 \pm 0.15,12.25 \pm 0.44 \mathrm{sec}$ post drug administration. Scoring of NLB formulation was calculated (Table 5).

\section{Pharmacoscintigraphy evaluation: Radiolabeling of NLB with ${ }^{99 m} T c$}

Radiolabeling of NLB with ${ }^{99 \mathrm{~m}} \mathrm{Tc}$ - Pertechnetate was optimized using a different concentration of stannous chloride at different temperature (Table 6,7). At $30^{\circ} \mathrm{C}$ and $\mathrm{pH}$ 6.0, the radiolabeling efficiency was found to be maximum and optimized (Figure 6). Labeling efficiency (LE) of ${ }^{99 \mathrm{~m} T c-N L B}$ radio complex was calculated up to $24 \mathrm{~h}$. 
Table 3: Physicochemical evaluation of NLB nasal drop.

\begin{tabular}{|c|c|c|c|c|c|}
\hline Formulation Code & Physical Appearance & Viscosity (Centipoises) & Osmolarity (milliosmol/litre) & pH & Clarity \\
\hline F1 & Golden Yellow & $1.3 \pm 0.15$ & 250 & $5.6 \pm 0.07$ & Clear \\
\hline F2 & Golden Yellow & $1.6 \pm 0.12$ & 258 & $5.8 \pm 0.18$ & Clear \\
\hline F3 & Golden Yellow & $2.0 \pm 0.10$ & 265 & $6.1 \pm 0.14$ & Clear \\
\hline F4 & Golden Yellow & $2.3 \pm 0.10$ & 270 & $6.3 \pm 0.22$ & Clear \\
\hline F5 & Golden Yellow & $2.5 \pm 0.13$ & 288 & $6.4 \pm 0.10$ & Clear \\
\hline F6 & Golden Yellow & $2.7 \pm 0.20$ & 285 & $6 \pm 0.05$ & Clear \\
\hline F7 & Golden Yellow & $2.9 \pm 0.23$ & 286 & $6.8 \pm 0.12$ & Clear \\
\hline F8 & Golden Yellow & $2.9 \pm 0.05$ & 287 & $6.2 \pm 0.16$ & Clear \\
\hline F9 & Golden Yellow & $3.3 \pm 0.34$ & 285 & $6.9 \pm 0.25$ & Clear \\
\hline F10 & Golden Yellow & $3.6 \pm 0.30$ & 280 & $6.9 \pm 0.28$ & Clear \\
\hline
\end{tabular}

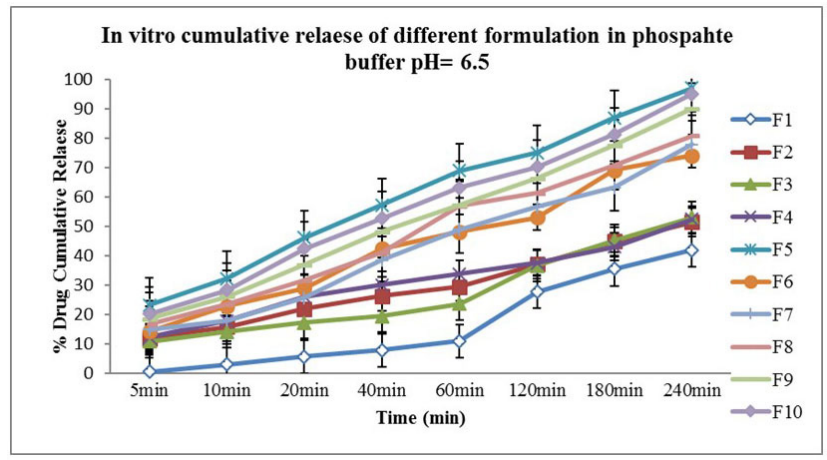

Figure 3: In vitro drug release profile of NLB Nasal drop Formulations (F1 to $F 10),(n=3)$. All values were expressed in Mean \pm SEM. Statistical analysis were carried out by using one-way ANOVA, followed by tukey's multiple comparison test.
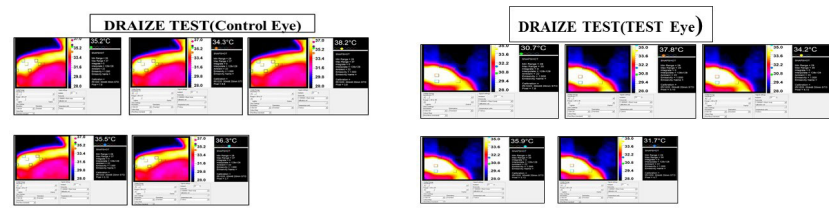

Figure 4: Represents temperature of Rabbit eye taken as control with I.R camera at different region. (b) Represents temperature of Rabbit eye taken as Test.

\section{Stability of NLB formulation}

In-vitro saline stability studies were performed. The ${ }^{99 \mathrm{~m}} \mathrm{Tc}-\mathrm{NLB}$ was found to be stable in saline and the maximum radiolabelling efficiency was determined to be $>95 \%$. The radiolabelling of NLB was found to be stable in saline with $96.45 \pm 2.25 \%$ at the end of 24 hr (Figure 7). The radiolabeled complex was found to be stable and there was no significant breaking of the radiolabeled drug complex.

Similarly, In-vivo stability of NLB radiolabeled complex was determined in serum and radiolabeling efficiency at the end of $24 \mathrm{hr}$ was found to be $95.12 \pm 0.15 \%$, thus it can be used for scintigraphy studies (Figure 7).
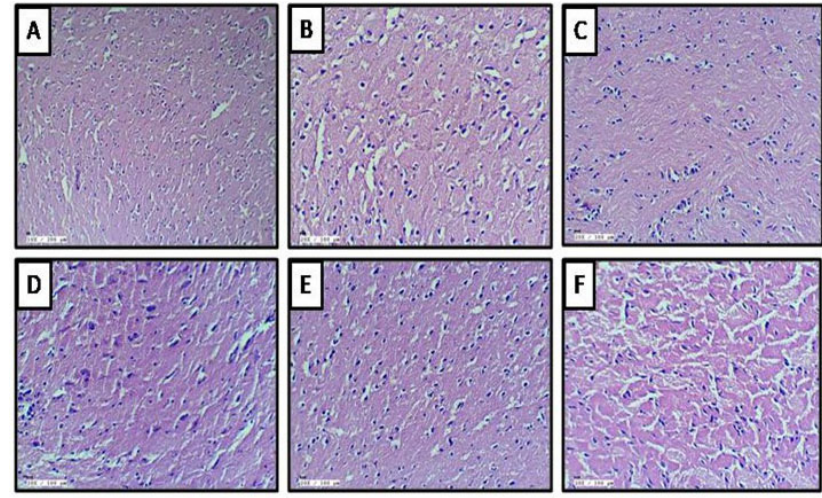

Figure 5: Histopathological examination of brain tissue section of rat after two weeks exposure to NLB Nasal delivery. A-C: Normal Control; D-F: Formulation Treated at $0.6 \mathrm{mg} / \mathrm{kg}$ dose.

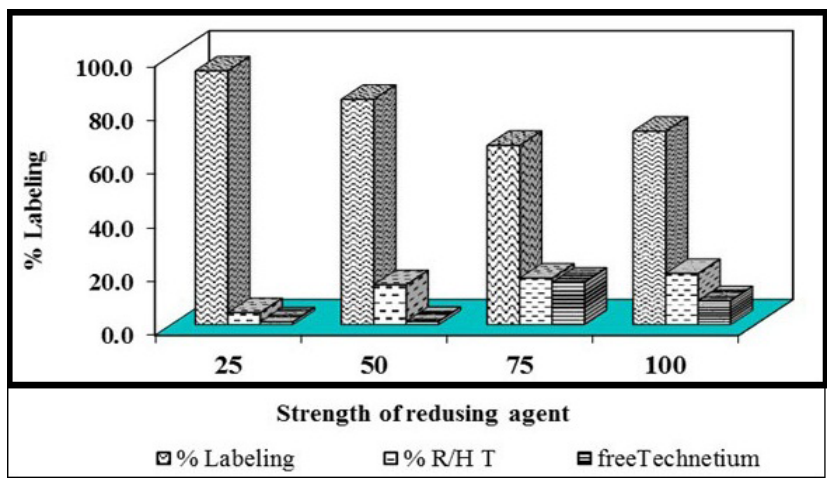

Figure 6: Comparative plot for determining the percent radiolabeling efficiency, percent hydrolyzed ${ }^{99 \mathrm{~m}} \mathrm{Tc}$ and percent free ${ }^{99 m}$ Tc.

In pharmacoscintigraphic study, NLB was radiolabeled with ${ }^{99 \mathrm{~m}} \mathrm{Tc}$-Pertechnatete as a radiotracer. Several reducing agents and factors were examined to achieve maximum radiolabeling efficiency. Radiolabeling efficiency was achieved to $<95 \%$ and it is confirmed by ITLS-SG chromatography methods. Stability studies (in-vitro and in-vivo) showed that radio-complex was stable up to $24 \mathrm{hr}$. 


\begin{tabular}{|c|c|c|c|c|}
\hline 동 & 琼 & $\begin{array}{l}m \\
+1 \\
\infty \\
ल \\
m\end{array}$ & $\begin{array}{l}\overline{i ்} \\
+1 \\
0 \\
\dot{m}\end{array}$ & $\begin{array}{l}\stackrel{N}{\infty} \\
\text { m } \\
m \\
\infty \\
\infty \\
\infty\end{array}$ \\
\hline 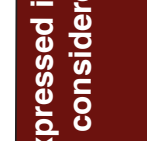 & 占き & $\begin{array}{l}\text { m } \\
\text { †1 } \\
0 \\
0 \\
\dot{\sim}\end{array}$ & 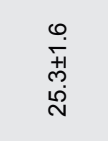 & 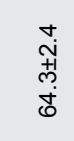 \\
\hline 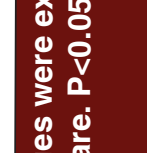 & 吠 & 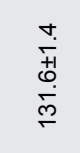 & $\begin{array}{l}\stackrel{0}{+} \\
\stackrel{+1}{N} \\
\stackrel{N}{\sim}\end{array}$ & 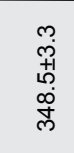 \\
\hline 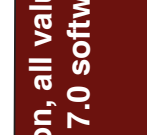 & ह & 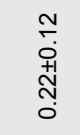 & 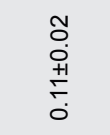 & $\begin{array}{l}\frac{m}{c} \\
\dot{+} \\
\stackrel{+1}{N} \\
0\end{array}$ \\
\hline 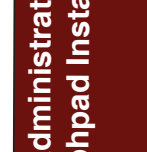 & 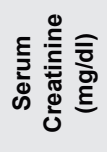 & $\begin{array}{l}5 \\
\text { +1 } \\
\text { 11 } \\
0 \\
0\end{array}$ & $\begin{array}{l}\infty \\
0 \\
0 \\
+1 \\
\infty \\
\text { ○. } \\
0\end{array}$ & 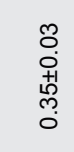 \\
\hline 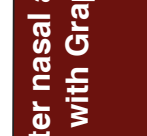 & 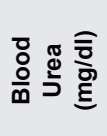 & $\begin{array}{l}0 \\
\stackrel{0}{+1} \\
\stackrel{+}{0} \\
\infty \\
\infty\end{array}$ & $\begin{array}{l}\stackrel{L}{i} \\
\text { in } \\
\text { p }\end{array}$ & 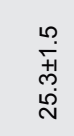 \\
\hline 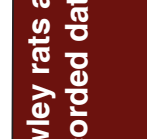 & 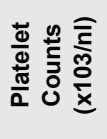 & 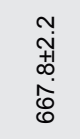 & 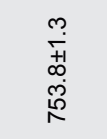 & $\begin{array}{l}\hat{N} \\
+1 \\
\infty \\
+ \\
+5\end{array}$ \\
\hline 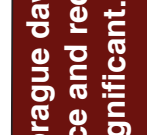 & $\begin{array}{l}\overline{\bar{z}} \\
\overline{0} \\
\text { i } \\
\tilde{D} \\
\infty\end{array}$ & 0 & 0 & 0 \\
\hline 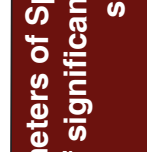 & 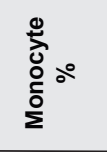 & 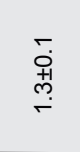 & $\begin{array}{l}0 \\
0 \\
\stackrel{+}{+1}\end{array}$ & 0 \\
\hline 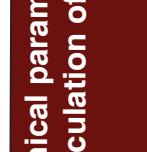 & 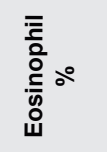 & 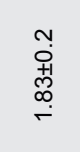 & $\begin{array}{l}m \\
0 \\
0 \\
01 \\
0 \\
-\end{array}$ & 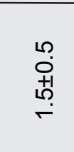 \\
\hline 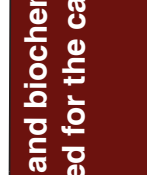 & 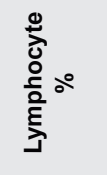 & 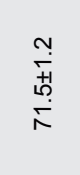 & $\begin{array}{l}\infty \\
\dot{0} \\
+1 \\
m \\
\dot{\sigma}\end{array}$ & $\begin{array}{l}\text { Ñ } \\
\text { †े } \\
\text { †े }\end{array}$ \\
\hline 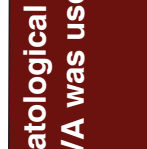 & $\begin{array}{l}\overline{\bar{z}} \\
\overline{\frac{2}{2}} \\
\frac{0}{3} \\
\frac{0}{2}\end{array}$ & $\begin{array}{l}0 \\
\dddot{i} \\
\infty \\
\infty \\
\dot{N}\end{array}$ & $\begin{array}{l}\check{\leftarrow} \\
\stackrel{+1}{N} \\
\infty \\
\stackrel{N}{N}\end{array}$ & 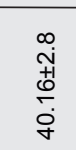 \\
\hline 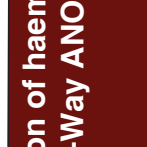 & 氞 & $\begin{array}{l}n \\
0 \\
0 \\
+1 \\
\infty \\
\infty \\
R\end{array}$ & 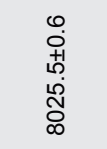 & 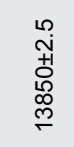 \\
\hline 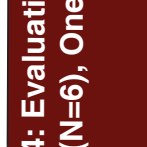 & 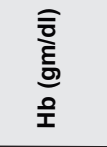 & $\begin{array}{l}\stackrel{O}{+} \\
\stackrel{+}{+} \\
\stackrel{+}{\leftarrow}\end{array}$ & 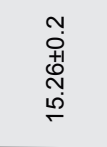 & 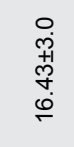 \\
\hline 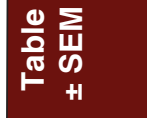 & $\begin{array}{l}\text { 을 } \\
\text { 인 }\end{array}$ & $\begin{array}{l}\overline{0} \overline{0} \\
\text { 을 } \\
\text { 잉 }\end{array}$ & 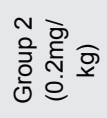 & 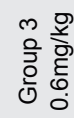 \\
\hline
\end{tabular}

\begin{tabular}{|c|c|c|c|c|}
\hline \multirow[t]{2}{*}{ S.No } & \multirow{2}{*}{$\begin{array}{l}\text { Time } \\
\text { (Min) }\end{array}$} & \multicolumn{3}{|c|}{ Response Time (Sec) } \\
\hline & & Control & I.N & I.M \\
\hline 1. & 10 & $1 \pm 0.04$ & $6.00 \pm 0.41$ & $3.54 \pm 0.34$ \\
\hline 2. & 20 & $2 \pm 0.18$ & $8.24 \pm 0.15$ & $5.35 \pm 0.09$ \\
\hline 3. & 60 & $1 \pm 0.08$ & $12.25 \pm 0.44$ & $7.21 \pm 0.06$ \\
\hline
\end{tabular}

\begin{tabular}{|c|c|c|c|c|}
\hline \multicolumn{5}{|c|}{ Pain Score on scale of 0-2 } \\
\hline S.No & $\begin{array}{c}\text { Time } \\
\text { (Min) }\end{array}$ & Control & I.M & I.N \\
\hline 1. & 0 & $\begin{array}{c}2 \\
\text { Orbital } \\
\text { Tightening) }\end{array}$ & $\begin{array}{c}2 \\
\text { (Orbital } \\
\text { Tightening) }\end{array}$ & $\begin{array}{c}2 \\
\text { (Orbital } \\
\text { Tightening) }\end{array}$ \\
\hline 2. & 30 & $\begin{array}{c}2 \\
\text { (Orbital } \\
\text { Tightening) }\end{array}$ & $\begin{array}{c}2 \\
\text { (Orbital } \\
\text { Tightening) }\end{array}$ & $\begin{array}{c}1 \\
\text { (Nose and } \\
\text { Cheek } \\
\text { flattening) }\end{array}$ \\
\hline
\end{tabular}

Table 6: Effect of $\mathrm{pH}$ on radiolabeled drug mean \pm SD

(Standard deviation) ( $\mathrm{N}=3$ ), statistical analysis was

carried out by using one-way ANOVA, followed by tukey's multiple comparision test.

\begin{tabular}{|c|c|}
\hline $\mathbf{p H}$ of Medium & \% Labeling Efficiency \pm S.D $(\boldsymbol{n}=\mathbf{3})$ \\
\hline 4.0 & $89.24 \pm 0.82$ \\
\hline 6.0 & $95.46 \pm 0.78$ \\
\hline 7.0 & $96.58 \pm 0.54$ \\
\hline 8.0 & $85.25 \pm 1.45$ \\
\hline
\end{tabular}

Table 7: Effect of temperature on radiolabeling efficiency mean \pm SD $(N=3)$, statistical analysis was carried out by using one-way ANOVA, followed by tukey's multiple comparision test.

\begin{tabular}{|c|c|}
\hline Temperature $\left({ }^{\circ} \mathbf{C}\right)$ & $\begin{array}{c}\% \text { Labeling Efficiency } \\
\mathbf{I S . D}(\boldsymbol{n}=\mathbf{3})\end{array}$ \\
\hline $\mathbf{2 5}$ & $85.12 \pm 0.64$ \\
\hline $\mathbf{3 0}$ & $95.46 \pm 0.52$ \\
\hline $\mathbf{5 0}$ & $93.42 \pm 0.56$ \\
\hline $\mathbf{6 0}$ & $96.22 \pm 0.48$ \\
\hline
\end{tabular}

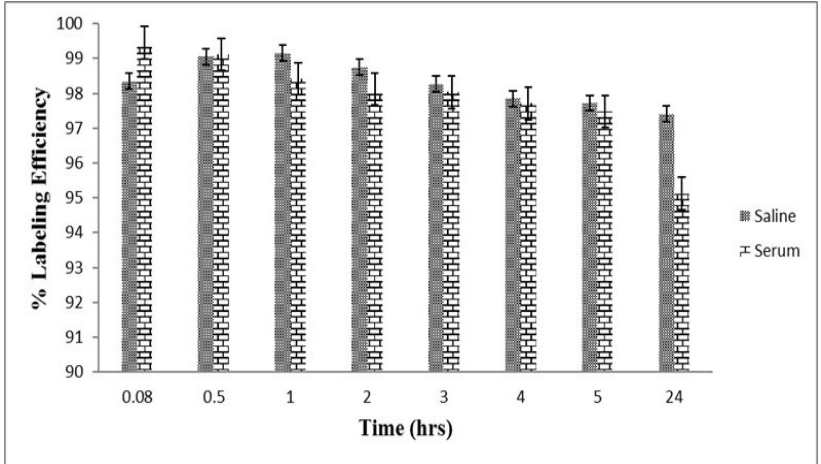

Figure 7: Stability of ${ }^{99 \mathrm{~m}} \mathrm{Tc}-$ Nalbuphine in saline and serum at $37^{\circ} \mathrm{C}$. 


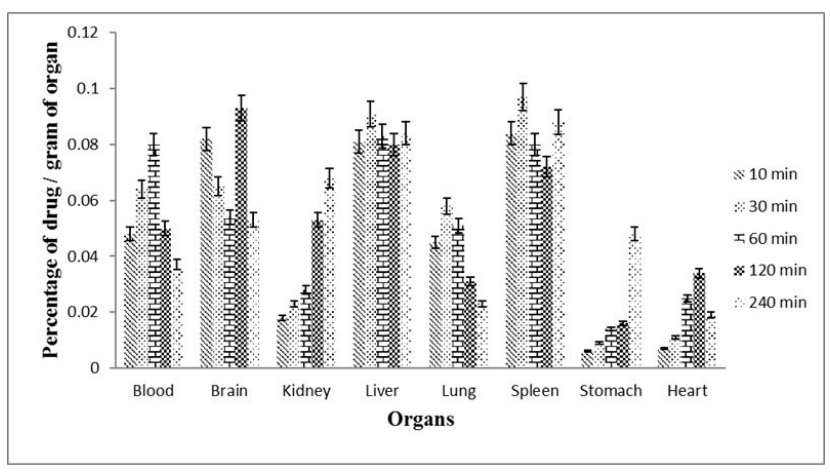

Figure 8: Graphical Representation for Biodistribution through NLB nasal route in Sprague dawley Rats.

\section{In vivo biodistribution studies in animal model}

Targeting efficiency was carried out following Singh $\mathrm{T}$ et al. $2012^{37}$ and is summarized in (Figure 8) indicating that the drug reached the target site in the first $10 \mathrm{~min}$ of intranasal administration and remained up to $240 \mathrm{~min}$. It was also observed that traces of the drug were found in other organs as well.

\section{Gamma Scintigraphy evaluation in animal model}

The behaviour of optimized formulation was observed by non-invasive pharmacoscintigraphy methods in the animal model (spargue dawley rat). Radiolabeled-NLB was given (2 drops/ nostrils) through the intranasal route to the animal and static images were acquired by gamma camera at 15, 30, 60, 120 and $240 \mathrm{~min}$. Gamma scintigraphy images showed that the radio complex was accumulating in the head area as a hot spot up to the last image. In the last images (240 min) radiotracer was found in the brain, stomach, liver, abdominal area of animal and quantified by drawing ROI (Region of Interest) on gamma camera images $(0.053 \pm 0.017$, $0.048 \pm 0.45,0.084 \pm 0.006)$. Segment A-E showed that the drug was retained in the brain which confirms the utility of developed formulation. A Pharmacoscintigraphy image of animals showed retention of radiolabeled-NLB in the brain up to $240 \mathrm{~min}$. The Gamma Scintigraphic images for the retention behaviour of NLB in the brain from mucoadhesive nasal formulation are depicted in (Figure 9).

\section{Stability studies of optimized formulation}

The stability of NLB nasal formulation was investigated. The formulations of NLB base stored in glass vials were taken out at predetermined intervals and scanned for absorbance at $\lambda_{\max } 284 \mathrm{~nm}$ and were further evaluated for physical appearance, $\mathrm{pH}$, osmolarity and drug content for 6 months. It was found that at the end of 6 months, a $4 \%$ change in assay from its initial value was observed which according to ICH, passes the stability study.
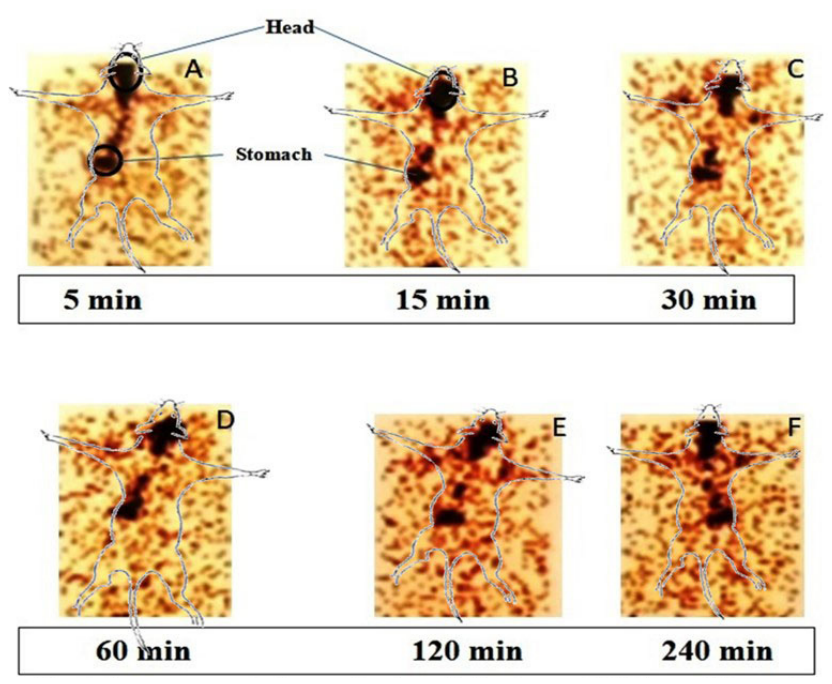

Figure 9: Drug accumulation and release behaviour of NLB nasal drop at different time intervals in animals using Gamma Scintigraphy.

\section{DISCUSSION}

From the last few decades' intranasal route gained growing interest not only for systemic but also nose to brain delivery of therapeutically active substance. The extensive vascularisation of nasal epithelia provides rapid availability of substance into blood. Several reports are also in favour of better intranasal bioavailability in comparison to intramuscular route. ${ }^{38}$ The maximum plasma concentration of intramuscular injection for the drug occurs after 30 mins of post administration. The maximum effect of drug after oral dosing is observed closer to $2 \mathrm{~h}$. It has also been proved that intranasal route provides direct access of active substance into brain through olfactory route, which is difficult in case of parenteral delivery. ${ }^{39}$ Numerous efforts are made to discover methods to obtain peak plasma concentration and therapeutic activity of drug in blood before $30 \mathrm{mins}$ and as close as possible to intravenous range. With the same context the present research work was carried out in an attempt to prepare NLB nasal drop formulation for its application in pain management during traumatic scenarios. NLB delivery through nasal route may be a choice for faster deposition into CNS, by crossing the Blood Brain Barrier (BBB). NLB drug delivery to the brain was delivered via the olfactory region of the nose in the experimental animals through nasal route and evaluation was done using gamma scintigraphy technique to assure its presence at the target site.

The pre-formulation studies were conducted to ascertain the quality, authenticity and characterization of NLB. The lambda max $\left(\lambda_{\max }\right)$ of NLB was observed at 
$284 \mathrm{~nm}$ which was found to be in accordance with earlier reported values, confirming the purity of the drug. Calibration curve was prepared in solvent i.e. phosphate buffer ( $\mathrm{pH}$ 6.5) because of the variability in the $\mathrm{pH}$ of nasal mucosa i.e. 5.5 to 6.5 in normal conditions. The partition coefficient (PC) of NLB was 1.39 which was approximately close to the reference value i.e.1.42. ${ }^{37}$ The experimental value imparts good permeability of drug through a biological membrane. FT-IR study confirmed no interaction between drug and excipients which indicated that chitosan may be used with NLB during formulation development. Chitosan used in NLB nasal formulation had reported for its good mucoadhesive properties due to positive charge, it can interact with the negative charge of the sialic acid residue in the mucosal layer. ${ }^{40,41}$ PEG-400 was used as a solvent to achieve desired nasal viscosity. Benzalkonium chloride was used as an antimicrobial preservative and $\mathrm{NaCl}$ for adjustment of tonicity of the nasal drop. The developed nasal drop formulation was evaluated for its physico-chemical properties including $\mathrm{pH}$, physical appearance, viscosity and percentage drug release, $\mathrm{pH}$ and viscosity of optimized NLB nasal formulation were found to be 6.4 at $2.5 \mathrm{cps}$. $\mathrm{pH}$ of the formulation was similar to nasal $\mathrm{pH}$, this indicates that prepared formulation would not cause any irritation or tissue damage during application. Developed NLB nasal formulation osmolarity was 288 which is isomolar to the nasal mucosa and the percentage drug release for NLB nasal drop was found to be $97.98 \%$ in the duration of $240 \mathrm{~min}$. The results obtained for all the parameters of formulation indicates suitability for nasal administration. A radiolabeling method was optimized using stannous salt as a reducing agent and ${ }^{99 \mathrm{~m}-}$ technetium pertechnetate as radioisotopes for non-invasive in-vivo distribution of NLB. The optimized protocol for radiolabeling showed more than $94.40 \pm 0.45 \%$ radiolabeling efficiency at an incubation time of $30 \mathrm{~min}$ with $95.46 \pm 0.52 \% \mathrm{R} / \mathrm{H}$. In-vitro saline and serum stability studies confirm that ${ }^{99 \mathrm{~m}} \mathrm{Tc}-\mathrm{NLB}$ complex was stable in saline and biological fluid i.e. Serum with $97.5 .25 \pm 1.05 \%$ and $96.0 \pm$ $2.25 \%$ of radiolabeling efficiency at the end of $24 \mathrm{hr}$ respectively. The radiolabeled complex was found to be stable and there was no significant breaking or leaching of technetium from the radiolabeled drug complex. The in-vivo toxicity studies in animals were conducted and various tests were performed i.e. daily monitoring of weight variation after nasal drug administration, biochemistry and histopathology of the brain were investigated. No significant changes in the weight of animals were observed and also there were no considerable increase in neutrophil, SGOT, SGPT, alkaline phosphatase, lymphocyte and platelet count levels. The histopathology of the brain demonstrated that the formulation was found to be non-toxic at a dose of 0.6 $\mathrm{mg} / \mathrm{kg}$. In-vivo efficacy study of NLB intranasal formulation using a hot plate was performed as this model is used to study the centrally acting analgesics. The heat latency in the rat was determined at 10, 30,60 min after administration in the animal model. It was observed that the response of rat with respect to time was $3.54 \pm 0.34$, $5.35 \pm 0.09,7.21 \pm 0.06 \mathrm{sec}$ respectively, whereas, in case of intranasal administration of NLB formulation, the result at same time interval was $6.00 \pm 0.41,8.24 \pm 0.15$, $12.25 \pm 0.44 \mathrm{sec}$ post drug administration. This increase in heat latency is because sensory nerves got sensitize and the nociceptors and the involvement of endogenous substances such as prostaglandins are minimized. ${ }^{42}$ From the results, it showed the onset of analgesic action of nalbuphine nasal formulation was within $10 \mathrm{~min}$ of administration.

The stable radio-complex formed and was evaluated further in an animal model for its efficacy and target delivery. Scintigraphy study indicated that radiolabeled ${ }^{99 \mathrm{~m}} \mathrm{Tc}-\mathrm{NLB}$ nasal drop crosses the blood brain barrier within10 min of administration and a uniform biodistribution of ${ }^{99 \mathrm{~m}} \mathrm{Tc}-\mathrm{NLB}$ was perceived in the brain at $240 \mathrm{~min}$. The content of the drug that reaches the brain from NLB formulation was found to be sufficient to suppress pain. It was found that the maximum concentration of NLB in the brain reaches in 10-15 min through the nasal route which was in correlation with in-vitro results. NLB administration by nasal route showed that drug reaching the stomach was minimum which confirms the retention of drugs in the nose and its delivery to the brain. It is clearly shown in (Figure 9) that the maximum uptake of the formulation was seen in the brain, liver, kidney and followed by lungs, blood and spleen. The above-mentioned results illustrate that NLB formulation reaches the target site i.e. brain and high concentration was found in the liver, lungs and kidney because NLB undergoes first-pass metabolism and its clearance is through kidney and lungs. In the present study, there was no crystal growth in charging NLB nasal drop in an inverted position and this indicates that the formulation was stable when subjected to accelerated temperature conditions. The shelf life of developed formulation was established in an assay at $40^{\circ} \mathrm{C} \pm 2{ }^{\circ} \mathrm{C}$ and $75 \pm 5 \% \mathrm{RH}$ with acceptance criteria (upper and lower). Based on the results obtained from the study, it was found that optimized NLB formulation was stable for a long duration of time. Our study strongly showed the poten- 
tial of NLB nasal formulation as a novel method to relieve pain in traumatic conditions.

\section{CONCLUSION}

Optimized formulation (F5) was found to be the best for all parameters i.e physico-chemical, mucoadhesive and release property. Optimized Formulation (F5) conceded several in-vitro examinations lucratively i.e. IPQC (In process quality control) and stability. From the above studies, data obtained on the drug targeting approach and low dose could reduce systemic exposure side effects and assures patient compliance. Hence, it can be concluded that the developed formulation may be recommended for field use.

\section{ACKNOWLEDGEMENT}

Authors are thankful to the Director, Institute of Nuclear Medicine and Allied Sciences (INMAS), for providing guidance and necessary support for conducting this research work.

\section{CONFLICT OF INTEREST}

The authors declare no conflict of interest.

\section{ABBREVIATIONS}

CSF: Cerebrospinal Fluid; NLB: Nalbuphine; BBB: Blood-Brain Barrier; FT-IR: Fourier transform infrared; CNS: Central nervous system; ${ }^{99 \mathrm{~m}}$ Tc-Pertechnetate: $99 \mathrm{~m}$ Technecium Pertechnetate.

\section{REFERENCES}

1. Hudspith MJ, Siddall PJ, Munglani R. Physiology of pain, $2^{\text {nd }}$ ed. Elsevier Mosby. 2006.

2. Ray L, Lipton RB, Zimmerman ME, Katz MJ, Derby CA. Mechanisms of association between obesity and chronic pain in the elderly. Pain. 2011;152(1):53-9.

3. Mackenzie R. Analgesia and sedation. J R Army Med Corps. 2000;146:117-27.

4. Lee J. Social Science and Medicine The pill hustle: Risky pain management for a gunshot victim. Soc Sci Med. 2013;99:162-8.

5. Sanchez-Migallon GD, Kukanich B, Keuler NS, Klauer JM, Paul-Murphy JR. Antinociceptive effects of nalbuphine hydrochloride in Hispaniolan Amazon parrots (Amazona ventralis). Am J Vet Res. 2011;72(6):736-40.

6. Sanchez-Migallon GD, KuKanich B, Heath TD, Krugner-Higby LA, Barker SA, Brown CS, et al. Pharmacokinetics of long-actingnalbuphine decanoate after intramuscular administration to Hispaniolan Amazon parrots (Amazona ventralis). Am J Vet Res. 2013;74(2):191-5.

7. Lo MW, Schary WL, JrWhitney CC. The disposition and bioavailability of intravenous and oral nalbuphine in healthy volunteers. J Clin Pharmacol. 1987;27(11):866-73

8. Fragen RJ, Caldwell N. Acute intravenous premedication with nalbuphine. Anesth Analg. 1977;56(6):808-12.

9. Costantino HR, Illum L, Brandt G, Johnson PH, Quay SC. Intranasal delivery: Physicochemical and therapeutic aspects. Int J Pharm. 2007;337(1-2):1-24.
10. Johnson $\mathrm{PH}$, Quay SC. Advances in nasal drug delivery through tight junction technology. Expert Opin Drug Deliv. 2005;2(2):281-98.

11. Illum L. Transport of drugs from the nasal cavity to the central nervous system. Eur J Pharm Sci. 2000;11(1):1-18.

12. Arora P, Sharma S, Garg S. Permeability issues in nasal drug delivery. Drug Discov Today. 2002;7(18):967-75

13. Wen MM. Olfactory Targeting Through Intranasal Delivery of Biopharmaceutical Drugs to the Brain - Current development. Discov Med. 2011;11(61):497-503.

14. Hanson LR, Frey WH. Intranasal delivery bypasses the blood-brain barrier to target therapeutic agents to the central nervous system and treat neurodegenerative disease. BMC Neurosci. 2008;9(3):S5.

15. Ritthidej GC. Nasal delivery of peptides and proteins with chitosan and related mucoadhesive polymers: In Peptide and protein delivery. Acedemic Press. 2011;47-68.

16. $\mathrm{Xu} \mathrm{X}$, Shen $\mathrm{Y}$, Wang $\mathrm{W}$, Sun $\mathrm{C}$, Li C, Xiong $\mathrm{Y}$, et al. Preparation and in vitro characterization of thermosensitive and mucoadhesive hydrogels for nasal delivery of phenylephrine hydrochloride. Eur J Pharm Biopharm. 2014;88(3):998-1004

17. Appasaheb PS, Manohar SD, Bhanudas SR. A Review on Intranasal Drug Delivery System. J Adv Pharm Edu and Res. 2013;3(4):333-46.

18. Xiao C, Davis FJ, Chauhan BC, Viola KL, Lacor PN, Velasco PT. Brain transit and ameliorative effects of intranasally delivered anti-amyloid- $\beta$ oligomer antibody in 5XFAD mice. J Alzheimer's Dis. 2013;35(4):777-88.

19. Kintz P. Hair Analysis, $4^{\text {th }}$ Editio. 1 Lambeth High Street, London SE1 7JN, UK 1559 St Paul Avenue, Gurnee, IL 60031, USA: Pharmaceutical Press. 2011.

20. Connell DW, The Octanol-Water Partition Coefficient. Handbook of Ecotoxicology. 1997;2(2):775-84.

21. Levin VA. Relationship of octanol/water partition coefficient and molecular weight to rat brain capillary permeability. J Med Chem.1980;23(6):682-4.

22. Sogias IA, Williams AC, Khutoryanskiy VV. Why is chitosan mucoadhesive? Biomacromolecules. 2008;9(7):1837-42.

23. Rajpal S, Mittal G, Sachdeva R, Chhillar M, Ali R, Agrawal SS, et al. Development of atropine sulphate nasal drops and its pharmacokinetic and safety evaluation in healthy human volunteers. Environ Toxicol Pharmacol. 2009;27(2):206-11.

24. Sharma N, Kulkarni GT, Sharma A. Development of Abelmoschus esculentus (Okra)-based mucoadhesive gel for nasal delivery of rizatriptan benzoate. Trop J Pharm Res. 2013;12(2)149-53.

25. Sharma N, Kulkarni GT, Sharma A, Bhatnagar A, Kumar N. Natural mucoadhesive microspheres of Abelmoschus esculentus polysaccharide as a new carrier for nasal drug delivery. J Microencapsul. 2013;30(6):589-98.

26. Datta R, Bandyopadhyay AK. A new nasal drug delivery system for diazepam using natural mucoadhesive polysaccharide obtained from tamarind seeds. Saudi Pharm J. 2006;14(2):115-9.

27. Innes A, Farrell AM, Burden RP, Morgan AG, Powell RJ. Complement activation by cellulosic dialysis membranes. J Clin Pathol. 1994;47(2):155-8.

28. Wilhelmus KR. The Draize eye test. Surv Ophthalmol. 2001;45(6)493-515.

29. Brat DJ. Practical Surgical Neuropathology: A Diagnostic Approach. Normal Brain Histopathology. 2010;15-33.

30. Porter MC, Hartnagel RE, Clemens GR, Kowalski RL, Bare JJ, Halliwell WE, et al. Preclinical toxicity and teratogenicity studies with the narcotic antagonist analgesic drug TR5379M. Fundam Appl Toxicol. 1983;3(5):478-82.

31. Dayan AD. Drug Discovery and Evaluation edited by HG Vogel and WH Vogel. Hum Exp Toxicol. 1998;17(10):591-1.

32. Banerjee T, Singh AK, Sharma RK, Maitra AN. Labeling efficiency and biodistribution of Technetium-99m labeled nanoparticles: Interference by colloidal tin oxide particles. Int J Pharm. 2005;289(1-2):189-95.

33. Sharma BG, Kumar N, Soni S, Rawat HS, Singh T, Mittal G, et al. Development and characterization of budesonide pressurized metered dose inhaler using gamma scintigraphy. Indian J Nucl Med. 2010;25(3):84

34. Krishnaiah YSR, Satyanarayana S, Rama PYV, Rao SN. Gamma scintigraphic studies on guar gum matrix tablets for colonic drug delivery in healthy human volunteers. J Control Release. 1998;55(2-3):245-52.

35. Goins B, Klippe RR, Rudolph AS, Cliff RO, Blumhardt R, Phillips WT. Biodistribution and imaging studies of technetium-99m-labeled liposomes in rats with focal infection. J Nucl Med. 1993;34(12):2160-8. 
36. Sharma BG, Kumar N, Nishad DK, Khare NK, Bhatnagar A. Development of microbial trigger based oral formulation of Tinidazole and its Gamma Scintigraphy Evaluation: A promising tool against anaerobic microbes associated GI problems. Eur J Pharm Sci. 2016;89:94-104.

37. Singh T, Kumar N, Soni S, Rawat H, Mittal G, Singh AK, Bhatnagar A. A new method for radiolabeling of immunoglobulin- $G$ and its biological evaluation. $J$ Pharm Bioall Sci. 2012;4(4):286-90.

38. Miller JL, Ashford JW, Archer SM, Rudy AC, Wermeling DP. Wermeling Comparison of intranasal administration of haloperidol with intravenous and intramuscular administration: A pilot pharmacokinetic study. Pharmacotherapy. 2008;28(7):875-82.
39. Erdő F, Bors LA, Farkas D, Bajza Á, Gizurarson S. Evaluation of intranasal delivery route of drug administration for brain targeting. Brain Resaerch Bulletin. 2018;143:155-70

40. Soane RJ, Frier M, Perkins AC, Jones NS, DavisSS, Illum L. Evaluation of the clearance characteristics of bioadhesive systems in humans. Int J Pharm. 1999;178(1):55-65.

41. Soane RJ, Hinchcliffe M, Davis SS, Illum L. Clearance characteristics of chitosan based formulations in the sheep nasal cavity. Int $\mathrm{J}$ Pharm. 2001;217(1-2):183-91.

42. Pinho-Ribeiro FA, Verri WA, Chiu IM. Nociceptor sensory neuron-immune interactions in pain and inflammation. Trends Immunol. 2016;38(1):5-19.

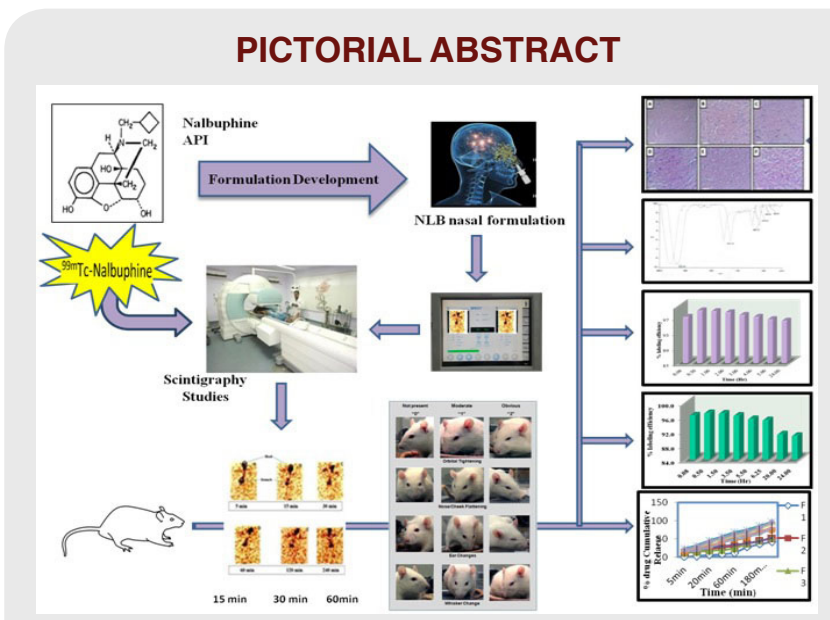

\section{SUMMARY}

Nalbuphine (NLB) is an approved opioid analgesic for the management of severe pain in wounds, battlefield injuries and is recommended to subsidize labour pain during childbirth. The study aims to develop an intranasal opioid formulation for faster pain relief. Secondly to avoid patient inconvenience and make it available for buddy care as compared to available parenteral formulations which require skilled persons for their administration. In case of war, accidents or any natural calamities incidents, the feasibility of giving drug from the parenteral route is not feasible as it requires high skilled medic/paramedic staff.

Cite this article: Khanna K, Sharma D, Karwasra R, Sharma N, Nishad DK, Popli H, et al. Intranasal Nalbuphine Formulation for Faster Management of Pain in Prehospital Scenario; Its Safety and Comparative Efficacy in Animal Models. Indian J of Pharmaceutical Education and Research. 2020;54(2):310-22. 